\title{
PERKEMBANGAN POLA SPASIAL KAMPUNG PADA SENTRA USAHA BERBASIS RUMAH TANGGA (UBR)
}

\author{
Pindo Tutuko* \\ Program Studi Arsitektur Universitas Merdeka Malang \\ * pindotutuko@yahoo.com
}

\begin{abstract}
ABSTRAK
Penelitian ini merupakan penelitian lanjutan dari penemuan adanya pola perkembangan hunian rumah produktif kampung Sanan "Tempe" (Tutuko, 2004). Pada penelitian kali ini akan diteliti perubahan yang terjadi pada aspek permukiman dan lingkungan hunian Usaha Berbasis Rumah Tangga (UBR) UKM. Harapan yang akan dicapai adalah menemukan pola spasial kampung akibat perkembangan UBR dan kondisi permukiman dari aspek fisik. Metode yang digunakan untuk penelitian kualitatif ini adalah metoda penelitian perkembangan. Untuk mendapatkan hasil yang diinginkan, pendekatan yang dilakukan untuk melakukan studi tentang perkembangan rumah produktif adalah dengan menggunakan teori pengembangan rumah oleh Silas (1993). Sedangkan untuk menelusuri hal-hal yang perlu diperhatikan, hasilnya ditampilkan dalam bentuk diagramatis, ditunjang oleh kognisi lingkungan yang dikemukakan oleh Rapoport (1977). Hasil penelitian adalah mengkategorikan faktor-faktor perkembangan pola spasial kampung berdasarkan 5 aspek, yaitu: 1) Perkembangan bentuk dan pola permukiman; 2) Ruang dan lahan dalam permukiman dan perkembangannya; 3) Prasarana dasarpermukiman; 4) Aspek permukiman; dan 5) Pembangunan oleh masyarakat
\end{abstract}

Kata Kunci - Pola Hunian, Perkembangan, Permukiman, Rumah Produktif.

\section{PENDAHULUAN}

\section{Latar Belakang}

Rumah bukanlah hanya sekedar having, namun sudah menjadi bagian dari being dan becoming mereka. Oleh karena itu menurut Silas (1993) melihat rumah tidak cukup hanya dilihat dari aspek kuantitatif melalui prospek fisik saja, namun perlu juga dilihat dari aspek kualitatif menyangkut dimensi kebutuhan biologis, psikologis, sosial, dan ekonomi keluarga yang besangkutan. Selanjutnya Kecenderungan penambahan ruang dipengaruhi oleh beberapa aspek antara lain personal space, privacy, teritoriality, crowding, dan density, peta mental serta stress (Sarwono,SW, 1992).
Penelitian ini merupakan penelitian lanjutan dari penemuan adanya pola perkembangan hunian rumah produktif kampung Sanan "Tempe" (Tutuko, 2004). Pada penelitian kali ini akan diteliti perubahan yang terjadi pada aspek permukiman dan lingkungan hunian Usaha Berbasis Rumah Tangga (UBR) UKM. Harapan yang akan dicapai adalah menemukan pola spasial kampung akibat perkembangan UBR dan kondisi permukiman dari aspek fisik.

\section{Rumusan Masalah}

1. Apakah terdapat perkembangan pola spasial kampung sentra UBR akibat perkembangan sosial dan ekonomi warganya? 
2. Bagaimana perkembangan spasial yang terjadi pada kampung sentra UBR tersebut?

3. Faktor-faktor apa yang mendukung perkembangan pola spasial kampung sentra UBR agar berkelanjutan?

\section{Tujuan Penelitian}

Tujuan penelitian ini adalah sebagai berikut:

1. Mempelajari pola spasial kampung sentra UBR dan perkembangan rumah UBR-nya.

2. Mempelajari hal-hal yang tetap dipertahankan dalam perkembangan pola kampung tersebut.

3. Mempelajari faktor-faktor yang menjadikan pola spasial kampung Sanan 'Tempe' bertahan dalam lingkungan pendukungnya

\section{PEMBAHASAN}

\section{Perkembangan Bentuk dan Pola Permukiman}

Perkembangan bentuk dan pola permukiman merupakan cermin dari kedinamisan masyarakat yang ada pada permukiman tersebut. Pada dasarnya perkembangan permukiman dapat diperhatikan dari dua arah, yaitu perkembangan secara kualitas dan secara kuantitas. Hubungan keduanya dalam skala makro merupakan hubungan yang kompleks, maka perkembangan suatu wilayah tidak dapat dilihat secara terpisah dari lingkungannya.

Menurut Steadman (1983) perkembangan bentuk tidak lepas dari ilmu Morfologi (Ilmu Bentuk).

"Morphology" is the word which Goethe coined to segnify a universal science of form and spatial structure"

"Morphological":
- Rules of connection, interaction, position, dimentioning, functioning etc.

- The interweaving of defferent types to more or less organized composition.

\section{Ruang dan Lahan dan Perkembangan (Perluasan) Permukiman}

Banyak ditemui kawasan perumahan dan permukiman yang telah melebihi daya tampung dan daya dukung lingkungan, dalam menghadapi dampak saling keterkaitan dengan kawasan yang lebih luas, serta masalah keterpaduannya dengan sistem prasaranan dan sarana baik di perkotaan maupun di pedesaan.

\section{Konsep Pembangunan Berkelanjutan}

Pembangunan berkelanjutan meliputi aspek sosial, ekologi dan ekonomi yang masing-masing saling terkait untuk membentuk pembangunan wilayah yang terintegrasi. Pada permukiman yang diamati hal tersebut dilakukan dengan peningkatan mutu lingkungan dan peningkatan kemampuan masyarakat dalam bidang ekonomi. Peningkatan perekonomian masyarakat dilakukan dengan jalan memperbaiki antar wilayah dalam kota dan penyediaan sarana-prasarana lingkungan yang menunjang.

\section{Rumah dan Permukiman}

Komunitas merupakan suatu konsep dinamis yang mencerminkan suatu struktur hubungan, sikap dan tata nilai kehidupan yang berlaku pada satu kurun waktu tertentu dan terjadi pada level lokal. Pengertian tersebut ada dua hal yang dapat ditarik yaitu bahwa ada 
keterkaitan antara komunitas dengan tempatnya dan bahwa komunitas terbentuk karena kurun waktu. Komunitas dapat ditinjau dan dua aspek yaitu aspek sosial dan aspek fisik. Aspek sosial, komunitas adalah suatu kesatuan masyarakat yang diikat oleh tata nilai yang berlaku dalam masyarakat tersebut. Ikatan tersebut dapat berbentuk kekeluargaan, ketetanggaan, teman atau ikatan yang lebih ]uas lagi, yang sifatnya dapat formal maupun informal. Dilihat dari aspek fisik, komunitas adalah suatu area geografis tertentu yang merupakan permukiman. Karakteristik sosial budaya pemukim dan karakteristik alamiah maupun buatan yang ada di kawasan tersebut bertindak sebagai pengikat dan area tersebut.

Selanjutnya berkenaan dengan persepsi akan arti pentingnya rumah Silas (1993) menjelaskan ada 2, yaitu:

1. Rumah merupakan salah satu kebutuhan dasar manusia, setelah sandang dan pangan disamping pendidikan dan kesehatan, yang berfungsi sebagai tempat pelindung dan pengaman manusia dari pengaruh dan gangguan alam/cuaca maupun makhluk lain.

2. Rumah beserta lingkungannya (permukiman) merupakan pusat kegiatan keluarga, pendidikan, pembentukan kepribadian dan nilai budaya suatu komunitas serta sebagai tempat persemaian generasi yang akan datang yang dapat melambangkan peradaban manusia serta dapat menjadi cermin jati diri dan taraf hidup penghuninya sebagai gambaran peri kehidupan dan penghidupan yang menyeluruh.

Hal tersebut juga dipertegas oleh Newmark (1977) mengenai istilah tentang rumah sebagai tempat tinggal, antara lain:
1) Shelter (sebagai suatu tempat berlindung secara fisik).

2) House (sebagai tempat bagi manusia untuk melakukan kegiatan sehari-hari).

3) Home (sebagai tempat tinggal atau hunian bagi seseorang atau keluarga yang merupakan sebuah lingkungan psiko-sosial).

Dengan demikian, pengertian dari rumah lebih banyak diungkapkan sebagai home, yaitu sebuah tempat tinggal (fisik) seseorang atau keluarga untuk melakukan aktivitas sehari-hari (sosial) dan sebagai tempat berlangsungnya proses pengembangan diri (budaya).

\section{Rumah Produktif}

Menurut Silas (1993), bagi masyarakat fungsi rumah bukan hanya sekedar tempat berteduh, beristirahat dan berkeluarga (sebagai hunian) namun rumah bisa juga berfungsi untuk menggalang sumberdaya yang dimiliki penghuni dengan melihat peluang yang ada. Pada umumnya konsep rumah dan kerja termasuk dimensi sosial dan budaya. Beberapa detail rumah dapat diuraikan sebagai berikut:

- Rumah (saja), yaitu rumah yang digunakan sebagai tempat tinggal tanpa kegiatan lain yang berarti.

- Rumah Produktif, yaitu rumah yang sebagian digunakan untuk produktif atau kegiatan ekonomis, konsekuensinya juga timbul hubungan antara aspek produksi dan perawatan rumah.

\section{Pola Hunian Rumah Produktif Manusia dan Lingkungan}

Rapoport (1969) menyatakan, bahwa latar belakang budaya manusia yang berbeda-beda akan menentukan 
perilaku dan aktivitas manusia yang berbeda-beda pula. Sebagai akibatnya, berbagai sistem setting yang merupakan penampung sistem aktivitas kelompokkelompok manusia yang berbeda akan mempunyai karakter yang berbeda-beda pula. Perbedaan kelompok manusia yang berakibat pada perbedaan macam aktivitas maupun setting yang dibutuhkan bagi kegiatan tersebut. Jelas bahwa implikasinya pada penataan ruang tidak akan terlepas dari keharusan untuk melihat kekhususan aktivitas kelompok manusia yang berbeda tadi yang nampaknya sulit untuk disama-ratakan. Selanjutnya manusia dan lingkungan dalam kaitannya dengan aktivitas, sistem, setting, sistem setting, dan tata ruang dijelaskan sebagai berikut.

\section{Pendukung Rumah Produktif Sustainable Development}

Menurut Agenda 21 Indonesia, tujuan pembangunan perumahan dan permukiman adalah untuk mendukung aktivitas ekonomi dalam suatu sistem yang padu yang menjamin kelestarian daya dukung lingkungan dan sumberdaya alam, sehingga semua lapisan dan golongan masyarakat yang tumbuh dan berkembang oleh aktivitas tersebut terwadahi dalam permukiman yang menunjang kualitas hidup yang berkelanjutan.

\section{Perkembangan Rumah \\ Proses Bermukim}

Berbicara tentang proses bermukim tidak lepas dan pola pembangunan yang dilakukan oleh masyarakat. Menurut Baross (dalam Silas, 1993) pola pembangunan oleh masyarakat mempunyai urutan pertama dan terpenting adalah menduduki lahan, kemudian membangun dan terakhir adalah perencanaan. Harus dipahami bahwa pola masyarakat dalam membangun rumahnya bukan tumbuh linier, namun proses beragam tingkat rampung yang membaik secara dinamis dan berlanjut ${ }^{1}$.

\section{Housing as a Process}

Turner (1972) menjelaskan konsep tentang Housing as a Process yang berlandaskan tiga hal yaitu nilai rumah, fungsi ekonomi rumah dan wewenang atas rumah.

Menurut Habraken (1978) dalam perubahan tapak bangunan, yang menjadi subyek adalah ruang dan bentuk bangunan yang secara material memiliki volume, komposisi dan struktur.

\section{Kerangka Konsepsual}

Dari data sekunder dan beberapa tinjauan teori yang telah diungkapkan, maka disusun kerangka konsepsual penelitian yang berisi: konsep hunian, konsep perkembangan rumah produktif, dan konsep perkembangan pola hunian Rumah Produktif. Secara diagramatis konsep hunian dapat digambarkan sebagai berikut:

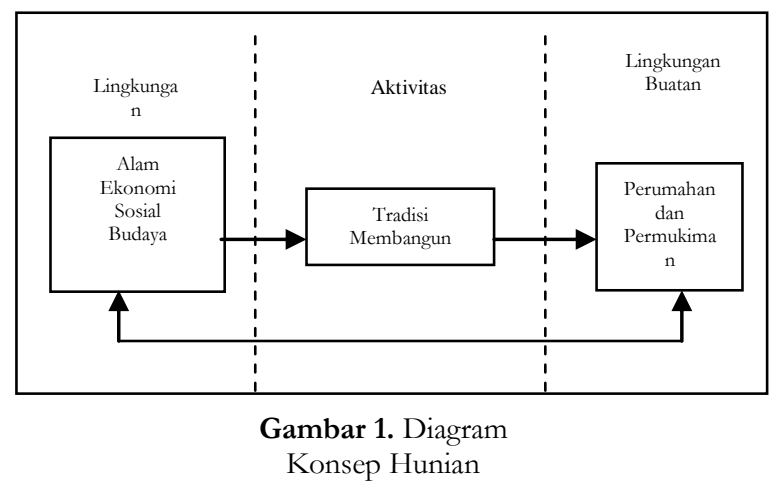

${ }^{1}$ Dimana terdapat 3 model diagram proses pengadaan perumahan, yaitu tradisional, modern, dan oleh masyarakat. 
Rumah sebagai fungsi ekonomi dikaitkan dengan hakekat perkembangan dan rumah produktif suatu arsitektur hunian dapat digambarkan pada diagram konsep perkembangan rumah produktif sebagai berikut:

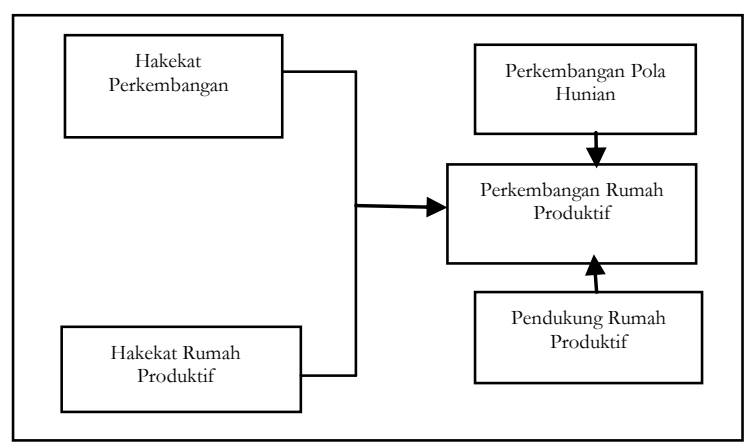

Gambar 2. Diagram Konsep

Perkembangan Rumah Produktif

\section{Perubahan Pola Hunian Kampung}

Sebagai akibat adanya pembukaan jalan poros UtaraSelatan pada jalur alternatif Timur kota Malang pada tahun 1985, kampung Sanan terbagi oleh jalan tersebut. Perubahan pola hunian ini tampak juga pada penataan rumah-rumah yang ada di bagian Barat. Dibandingkan dengan di bagian Timur, maka pada bagian Barat pola grid lebih menonjol terlihat, sedangkan di bagian Timur penataan rumahnya masih mengikuti pola jalan yang ada. Jika kita coba menarik garis diantara dua wilayah itu, maka terlihat adanya kesatuan yang menunjukkan bahwa rumah-rumah tersebut dulunya berada dalam satu kampung.

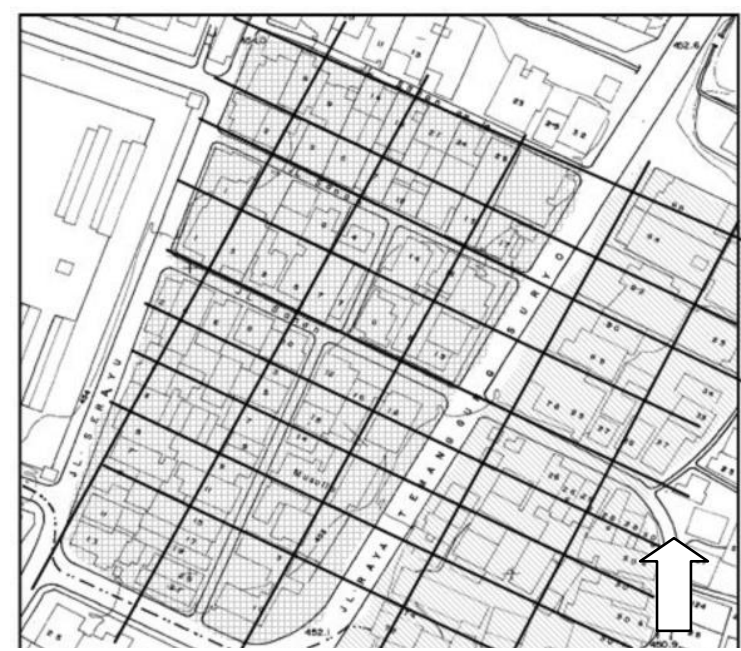

Gambar 3. Pola penataan rumah yang sama antara sisi Barat dan sisi Timur jalan (Sumber: Olah data dari Peta Garis BPN 1990-1991)

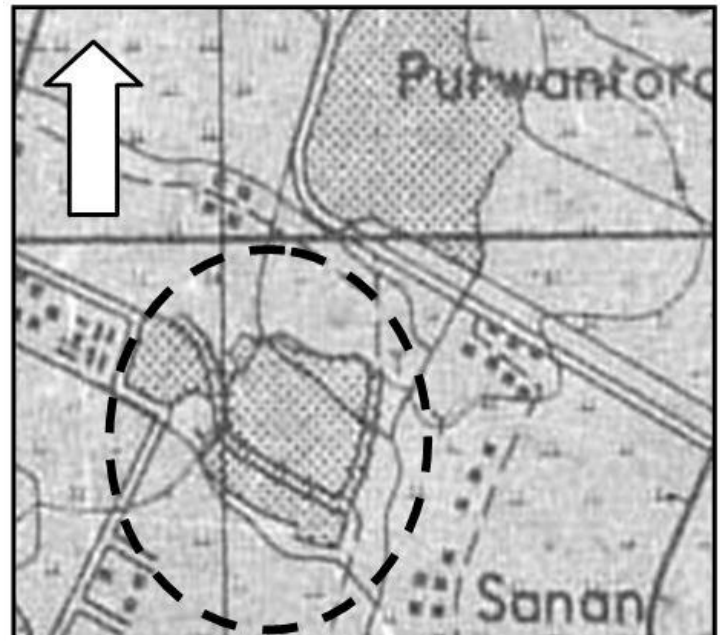

Gambar 4. Kampung Sanan yang dulu menjadi satu, tampak pada jalan utama kampung yang belum terpotong oleh jalan poros alternatif Utara-Selatan (Sumber: Kantor Proyek Pengembangan Kimpraswil Jatim) 


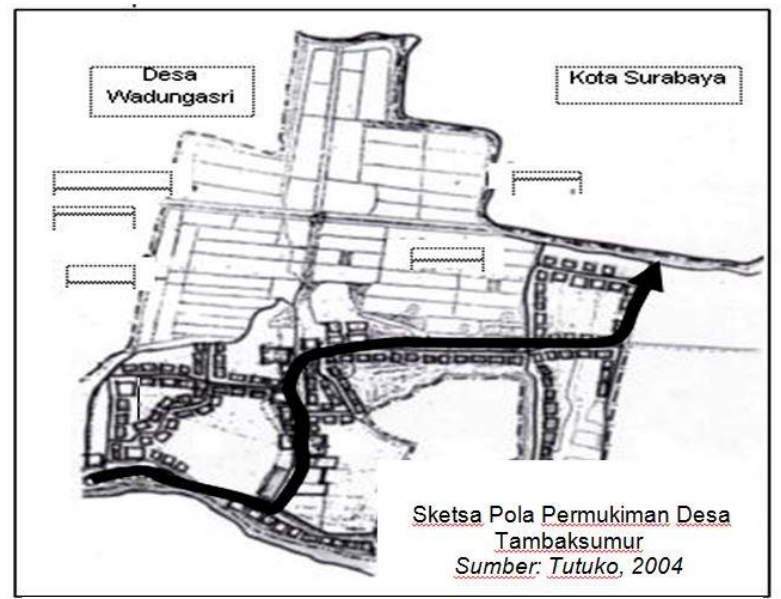

Gambar 5. Sketsa Pola Permukiman Desa Tambaksumur (Sumber: Tutuko, 2004)

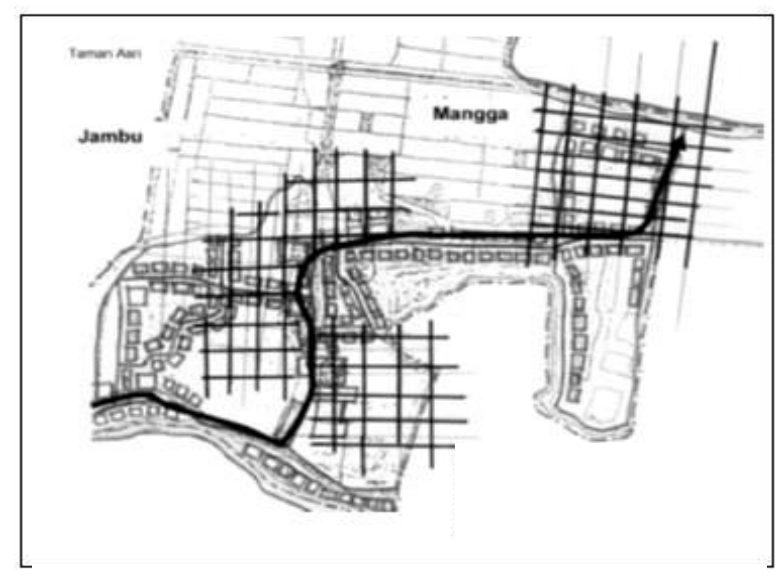

Gambar 6. Gabungan Pola Grid dan Linear (Sumber: Tutuko, 2004)
Penelitian lain dari Tutuko (2004) pada daerah Sidoarjo menujukkan bahwa perkembangan perkampungan secara alamiah dapat dilihat dari pola penataan fisik bangunan. Seperti Gambar 6 perumahan yang mengikuti akses jalan dan ada sebagian dari permukiman yang tidak berorientasi secara langsung terhadap jalan. Sedangkan pola penataannya berdasarkan pada teori bentuk linear.

Selanjutnya kecenderungan pola perkembangan pada perkampungan di Desa Tambak Sumur, mengarah pada pola perkembangan grid, dimana bangunan-bangunan baru dibangun dengan memanfaatkan pada lahan-lahan pekarangan yang kosong dan sudah tidak produktif. Sedangkan untuk lahan-lahan pertanian yang masih produktif tetap dipertahankan untuk memenuhi konsumsi pertanian (terutama padi). Sehingga nantinya terdapat gabungan antara bentuk grid dan bentuk linear. Jadi dapat disimpulkan bahwa terjadi perubahan secara geografis pada kampung Sanan ini. Selanjutnya akibat perubahan tersebut berpengaruh terhadap perubahan teritori secara produktif. Sedangkan pada bagian Utara, Timur, dan Selatan tidak mengalami perubahan baik secara administratif, geografis, dan produktif.

\section{Pendekatan yang Dilakukan \\ Dimensi Status-Nilai-Kendala}

Menurut Tutuko (2004), berdasarkan matriks hubungan Status-Nilai-Kendala, maka dalam penelitian ini jika status rumah dinyatakan sebagai Status, pendapatan keluarga per-bulan dinyatakan sebagai Nilai, dan sumber biaya perbaikan/pembangunan rumah 
dinyatakan sebagai Kendala, maka berdasarkan Tabel 1. sebagai berikut:

Tabel 1. Matriks Hubungan Status-Nilai-Kendala

\begin{tabular}{|c|c|c|c|}
\hline Kondisi & $\begin{array}{c}\text { Status } \\
\text { Kepemilikan } \\
\text { Rumah }\end{array}$ & $\begin{array}{c}\text { Nilai } \\
\text { Produktifitas } \\
\text { dari } \\
\text { pendapatan } \\
\text { Keluarga per- } \\
\text { bulan }\end{array}$ & $\begin{array}{c}\text { Kendala } \\
\text { Sumber biaya } \\
\text { perbaikan/pembangunan } \\
\text { rumah }\end{array}$ \\
\hline $\begin{array}{l}\text { Bangunan } \\
\text { milik } \\
\text { sendiri }\end{array}$ & Mantap & $\begin{array}{l}\text { Paling banyak } \\
\text { pada keluarga } \\
\text { yang } \\
\text { berpendapatan } \\
\text { Rp. } 500.000,- \\
\text { s/d Rp. } \\
750.000,-\end{array}$ & $\begin{array}{l}\text { Jaminan proses } \\
\text { pengembangan rumah } \\
\text { berasal dari tabungan } \\
\text { dan pinjam dari pihak } \\
\text { lain. }\end{array}$ \\
\hline $\begin{array}{l}\text { Bangunan } \\
\text { Sewa }\end{array}$ & Tumbuh & $\begin{array}{l}\text { Pada keluarga } \\
\text { yang } \\
\text { berpendapatan } \\
\text { Rp. 500.000,- } \\
\text { s/d Rp. } \\
\text { 750.000,- } \\
\end{array}$ & $\begin{array}{l}\text { Jaminan proses } \\
\text { pengembangan rumah } \\
\text { berasal dari tabungan. }\end{array}$ \\
\hline $\begin{array}{l}\text { Bangunan } \\
\text { milik } \\
\text { keluarga } \\
\text { (warisan) }\end{array}$ & $\begin{array}{l}\text { Tumbuh - } \\
\text { Mantap }\end{array}$ & $\begin{array}{l}\text { Pada keluarga } \\
\text { yang } \\
\text { berpendapatan } \\
\text { Rp. 500.000,- } \\
\text { s/d Rp. } \\
\text { 750.000,- }\end{array}$ & $\begin{array}{l}\text { Jaminan proses } \\
\text { pengembangan rumah } \\
\text { berasal dari tabungan }\end{array}$ \\
\hline
\end{tabular}

Sumber: Tutuko, 2004

Jadi proses pengembangan rumah oleh warga Sanan 'Tempe' berdasarkan 3 dimensi Status-Nilai-Kendala adalah sebagai berikut:

1. Status warga Sanan sebagian besar adalah pemilik rumah sendiri yang dapat dikatakan sebagai status mantap, sedangkan pada status bangunan sewa dan warisan (milik keluarga) dikatakan sebagai status tumbuh-mantap. Dikatakan demikian karena usaha yang dilakukan oleh penghuni baik sewa maupun warisan (milik keluarga) sudah dilakukan sejak lama, sehingga dalam pengalaman mengembangkan diri mereka sudah dapat dikatakan mantap, meskipun status bangunan bukan milik sendiri.

2. Kendala yang dihadapi oleh warga Sanan dalam mengadakan perbaikan atau pembangunan rumahnya nampak terlihat dari sumber biaya pembangunan rumah. Sebagian besar mereka mengatasi kendala sebagai jaminan dalam proses pengembangan rumahnya dengan menabung, sedangkan warga yang melakukan pinjaman ke pihak lain lebih berpeluang jika rumahnya milik sendiri.

3. Nilai rumah yang terkait dengan kemampuan anggota keluarga untuk nilai produktif bagi setiap status yang berbeda, sebagian besar melakukan untuk melanjutkan tradisi turun-temurun membuat tempe di kampung Sanan.

Jika ditinjau dari sisi ruang-dalam menurut Wibisono (2006), perubahan yang terjadi terdapat 3 jenis perubahan fisik ruang-dalam, yaitu 1) Tingkat perubahan kecil; 2) Tingkat perubahan sedang; 3) Tingkat perubahan besar; 4) Tanpa perubahan.. Hal ini juga yag mempengaruhi bentukan dari pola hunian dan oiomatis akan mempengaruhi pola kampung secara keseluruhan.

\section{Pola Hunian Kampung}

Pola perkembangan hunian kampung Sanan 'Tempe' sebagai berikut:

1. Penduduk Sanan terdiri dari dua jenis, yaitu asli dan pendatang (dari hasil wawancara). Pendatang sebagian besar berasal dari Pasuruan. Diperkirakan yang menjadi penyebab kedatangan orang Pasuruan ke kota Malang disebabkan status kota Malang pada 
tanggal 1 April 1914 sebagai Gemeente (Kota). Ditambah lagi dengan ibukota karesidenan yang semula di Pasuruan dipindah ke Malang. Hal inilah yang diperkirakan menjadikan penyebab banyaknya pendatang dari Pasuruan.

2. Dusun Sanan yang dulu banyak lahan persawahannya, kemudian dibangun rumah-rumah.

3. Karena Keterbatasan lahan dan kebutuhan akan rumah bagi keluarga baru (anak-anak mereka), maka dilakukan pola pembagian tanah berdasarkan warisan. Hal ini dilakukan setelah orang tua mereka meninggal.

4. Pola rumah yang terjadi merupakan rangkaian rumah-rumah dari suatu keluarga. Pola ini terjadi di sebagian besar tanah di kampung Sanan, sehingga tidak heran jika dalam satu kelompok rumah mereka merasa masih satu saudara.

5. Jika tiap rumah memiliki alasan yang sama dalam melakukan perkembangan rumah maka yang terjadi adalah permukiman yang rapat.

6. Pada permukiman yang rapat ini tumbuh generasi baru yang perlu rumah, maka tindakan yang dilakukan adalah dengan cara:

- Pindah dari kampung Sanan, tetapi dalam salah satu kasus di atas, ia kembali ke Sanan lagi dengan alasan tidak betah.

- Merenovasi rumah dengan cara menambah jumlah lantai.

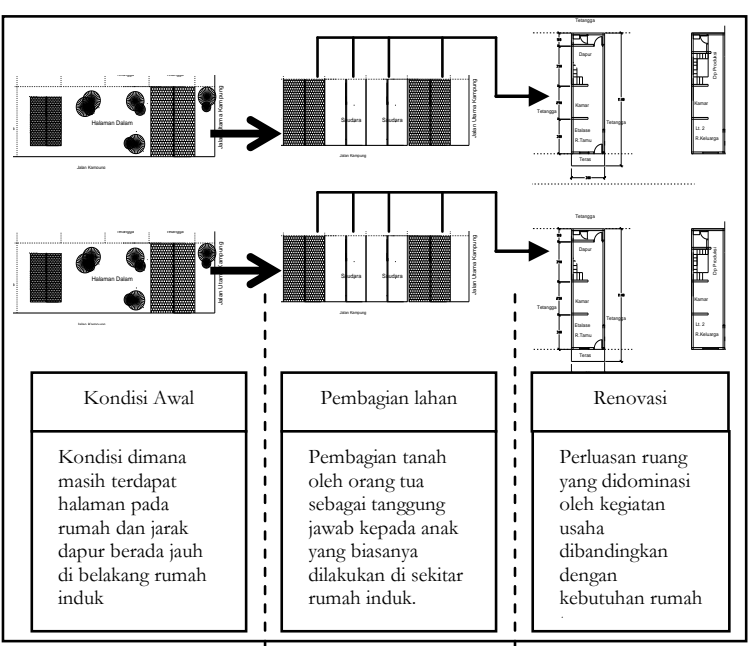

Gambar 7. Pola Perkembangan Hunian Kampung Sanan (Sumber: Tutuko, 2004)

\section{Pola Kawasan Kampung Sanan 'Tempe'}

Perkembangan pola hunian secara kawasan yang terjadi ditinjau dari orientasi dan teritori. Perkembangan ditinjau dari orientasi adalah kecenderungan arah perkembangan pola-pola kelompok hunian yang terjadi di kampung sedangkan secara teritori ditinjau aspek geografis dan aspek produktif. Perkembangan yang terjadi mengakibatkan terbentuknya zona-zona yang terjadi di kampung ini. Dengan munculnya zona-zona ini dapat dilihat kecenderungan perkembangan pola kawasan kampung Sanan 'Tempe' ditinjau dari orientasi, teritori geografis, dan teritori produk tichovasi rumah dengan cara me

\section{Orientasi Perkembangan Pola Kelompok Hunian}

Berdasarkan kondisi di lapangan maka orientasi perkembangan pola kelompok hunian dipengaruhi oleh 
bentuk Lahan. Bentuk ini mempengaruhi arah yang terbaik dalam melakukan perkembangan sebuah kelompok hunian. Terdapat 2 orientasi yaitu, perkembangan yang berorientasi ke belakang dan perkembangan yang berorientasi ke samping.

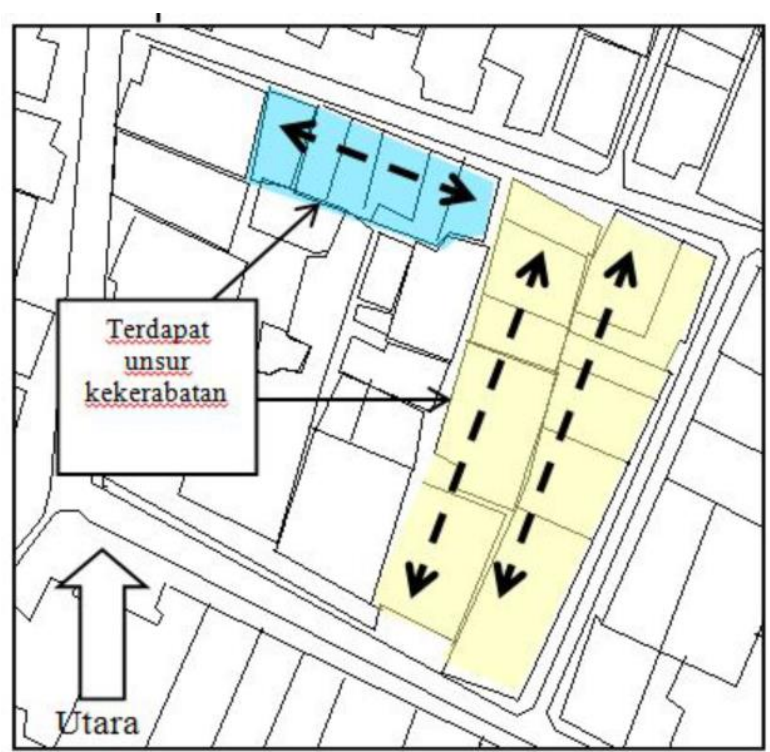

Gambar 8. Sketsa salah satu contoh Orientasi

Perkembangan Pola Kelompok Hunian yang terjadi di RW 15 (Sumber: Tutuko, 2004)

\section{Pola Kawasan ditinjau dari Teritori Geografis}

Dari sketsa (Gambar 9) menunjukkan bahwa pola perkembangan hunian secara kawasan mengikuti pola jalan utama kampung. Secara geografis mereka masih menyatu dengan permukiman di sisi Barat. RW 14 yang berada di sisi Barat jalan terpisah secara geografis dengan RW 14 yang berada di Timur jalan (posisi pintu masuk 'Sentra Indutri Tempe Sanan' berada di RW 14 yang berada di Timur jalan).

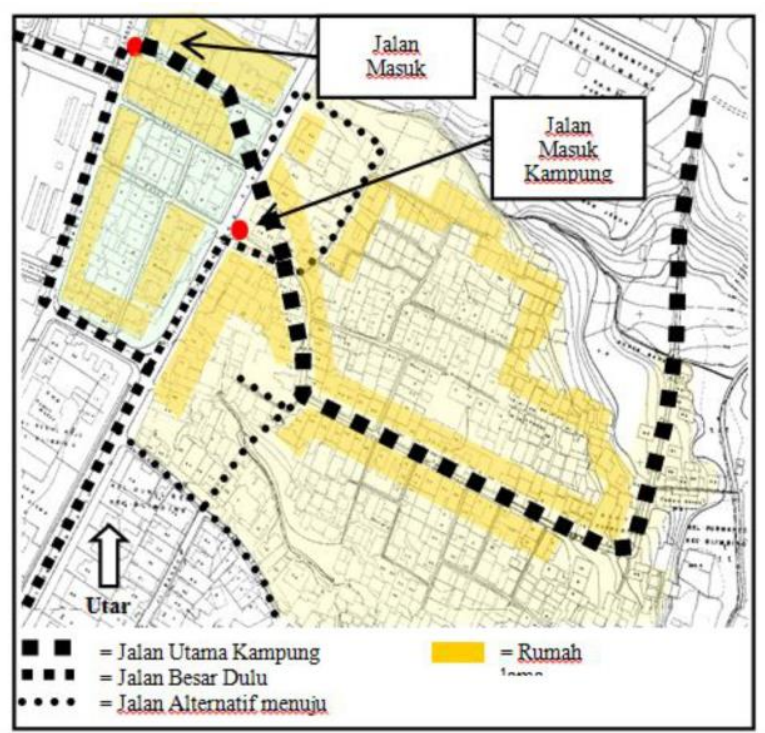

Gambar 9. Sketsa permukiman dan pola jalan tahun 1959 dan sekarang (Sumber: Tutuko, 2004)

\section{Pola Kawasan ditinjau dari Teritori Produktif}

Pola kawasan ditinjau dari teritori produktif mempengaruhi zona-zona kegiatan usaha yang terjadi di kampung ini. Dengan adanya kondisi tersebut, maka terdapat kondisi-kondisi sebagai berikut:

1. Terjadi perubahan pola-pola kegiatan usaha yang terdiri dari 3 kelompok yaitu .pembuat tempe, pembuat keripik tempe, dan penjual keripik tempe.

2. Terdapat distribusi barang yang berbeda-beda disebabkan faktor saling membutuhkan dari tiaptiap kelompok kegiatan usaha tempe tersebut. 
3. Terdapat pengelolaan limbah usaha yang berbedabeda tergantung dari jenis usaha yang dilakukan.

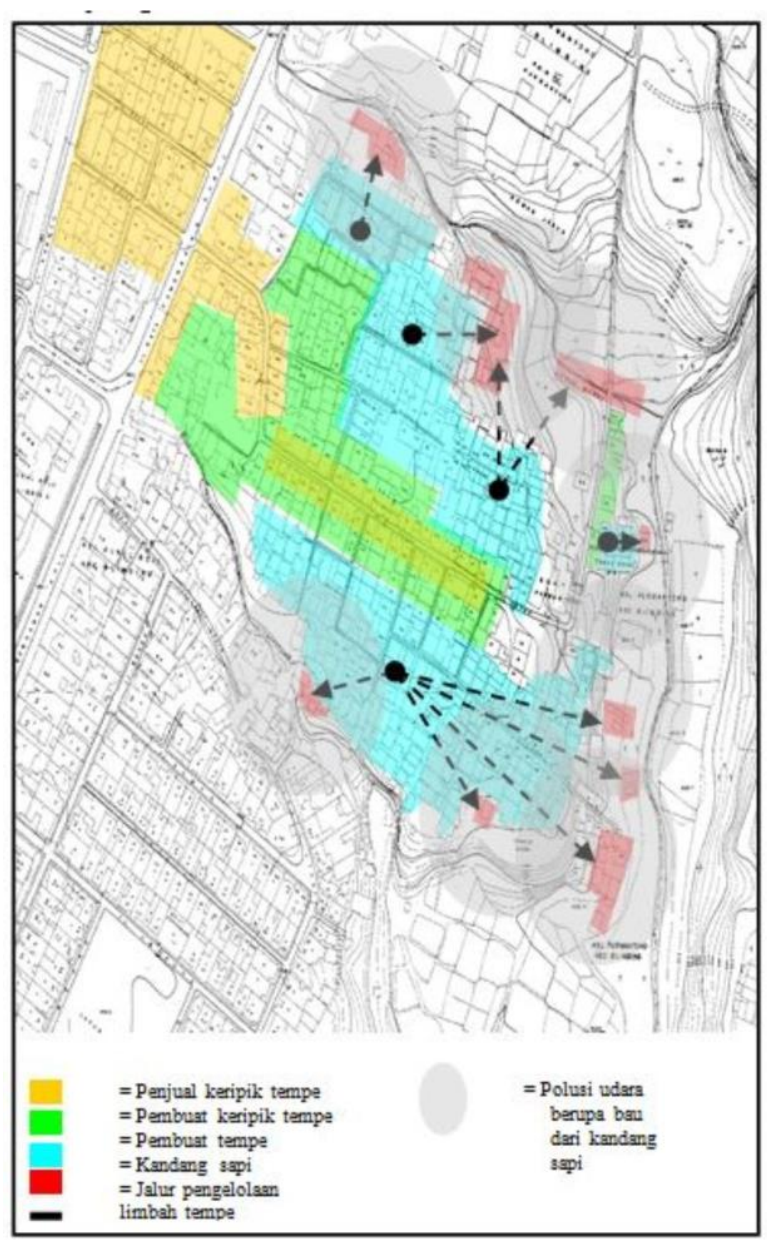

Gambar 10. Zona-zona kegiatan usaha dan distribusi pengelolaan limbah tempe. (Sumber: Tutuko, 2004)

\section{KESIMPULAN}

- Akibat pembangunan jalan alternatif Utara-Selatan pada tahun 1985 terjadi perubahan secara geografis pada kampung Sanan ini dan akibat perubahan tersebut berpengaruh terhadap teritori geografis dan teritori produktif.

- Kecenderungan arah perkembangan pola-pola kelompok hunian yang terjadi di kampung sedangkan secara teritori ditinjau aspek geografis dan aspek produktif. Perkembangan yang terjadi mengakibatkan terbentuknya zona-zona yang terjadi di kampung ini. Dengan munculnya zonazona ini dapat dilihat kecenderungan perkembangan pola kawasan kampung Sanan 'Tempe' ditinjau dari orientasi, teritori geografis, dan teritori produktif.

- Daya dukung permukiman di lingkungan kampung Sanan 'Tempe' terjaga dengan baik. Tampak dengan kondisi sarana dan prasarana lingkungan yang baik.

- Untuk menjaga keberlangsungan rumah produktif di kampung Sanan 'Tempe' ini, maka pengelolaan limbah di sebagian besar wilayah kampung dikelola dengan baik.

- Kesimpulan berupa tabel tentang struktur permukiman dan prasarana kota di kampung Sanan yang terdiri dari 5 aspek sebagai berikut:

\begin{tabular}{|c|c|c|}
\hline NO. & ASPEK & Kampung Sanan \\
\hline 1. & $\begin{array}{l}\text { Perkembangan } \\
\text { bentuk dan pola } \\
\text { permukiman }\end{array}$ & $\begin{array}{l}\text { - } \quad \text { Kecenderungan } \\
\text { perkembangan vertikal } \\
\text { dan interstisial } \\
\text { Pola permukimannya } \\
\text { gabungan antara pola } \\
\text { linear dan pola grid. }\end{array}$ \\
\hline 2. & $\begin{array}{l}\text { Ruang dan lahan } \\
\text { dalam permukiman } \\
\text { dan }\end{array}$ & $\begin{array}{l}\text { - Intensitas peñgutapat pe } \\
\text { lahan tinggi pada setiap } \\
\text { daerah kampung Sanan }\end{array}$ \\
\hline
\end{tabular}




\begin{tabular}{|c|c|c|}
\hline NO. & ASPEK & Kampung Sanan \\
\hline & perkembangannya & \\
\hline 3. & $\begin{array}{l}\text { Prasarana dasar } \\
\text { permukiman }\end{array}$ & $\begin{array}{l}\text { Sudah cukup terpenuhi } \\
\text { untuk prasarana dasar } \\
\text { permukiman. } \\
\text { Terdapat pembangunan } \\
\text { dalam rangka perbaikan } \\
\text { dan penyempurnaan } \\
\text { prasarana permukiman } \\
\text { seperti jalan dan jaringan } \\
\text { air bersih. }\end{array}$ \\
\hline 4. & Aspek permukiman & $\begin{array}{l}\text { - Sebagai permukiman yang } \\
\text { sudah cukup lama, maka } \\
\text { permukiman di Kampung } \\
\text { Sanan sudah terdapat } \\
\text { aspek-aspek permukiman } \\
\text { yang terus mengikuti } \\
\text { perkembangan kota. } \\
\text { Ruang terbuka kampung } \\
\text { terutama berupa areal } \\
\text { persawahan di sisi Timur } \\
\text { dan lapangan untuk } \\
\text { bermain. }\end{array}$ \\
\hline 5. & $\begin{array}{l}\text { Pembangunan oleh } \\
\text { masyarakat }\end{array}$ & $\begin{array}{l}\text { Belum adanya kebijakan } \\
\text { atau strategi di tingkat } \\
\text { atasnya. } \\
\text { Keberadaan Perum di } \\
\text { daerah Sulfat (Utara) } \\
\text { memberikan pengaruh } \\
\text { yang kuat } \\
\text { Proses perkembangan } \\
\text { yang mereka lakukan } \\
\text { adalah perlahan-lahan } \\
\text { masih menggunakan pola } \\
\text { tradisional } \\
\text { Musyawarah merupakan } \\
\text { sebuah pendekatan } \\
\text { kultural }\end{array}$ \\
\hline
\end{tabular}

Rekomendasi yang perlu dilakukan untuk mencapai hal tersebut adalah:

- Menjaga tradisi yang dilakukan secara turun temurun dengan menyesuaikan kondisi yang ada baik di rumah maupun di lingkungan rumah mereka.

- Dalam melakukan perubahan rumah produktif untuk tujuan pengembangan usaha dan kebutuhan rumah tangga tetap berpedoman pada zona-zona produksi yang terdapat pada tiap-tiap rumah. Selanjutnya perlu mengetahui pola-pola hunian rumah produktif mereka masing-masing sebagai acuan dalam menentukan arah perkembangan rumah dari sudut kepentingan produktif dan domestik.

- Memperhatikan pola perkembangan rumah produktif mereka dengan rumah produktif yang lain, sehingga pada akhirnya terdapat keselarasan dengan pola hunian kampung.

- Menjaga sarana dan prasarana lingkungan yang ada, karena daya dukung lingkungan yang terjaga akan menjamin proses keberlangsungan hidup (sustainable living).

\section{REFERENSI}

[1] ---Agenda 21 Indonesia, 1997, Strategi Nasional Untuk Pembangunan Berkelanjutan; Kantor Menteri Negara Lingkungan Hidup; Jakarta.

[2] ---International Research on Home Based Enterprises 2002, Indonesia-India-South AfricaBolivia; Laboratory of housing and Human Settlement Architecture-ITS, Surabaya.

[3] ---Sustainable Livehoods in The Integration of Informal Settlement in Asia, Latin America, and Africa, 2002, Architecture ITS Surabaya and International Council for Research and Innovation in Building and Constraction; UPTITS Press, First Edition, Surabaya.

[4] ---The CARDO International Conference on Housing, Work, and Development: The Role of Home-Based Enterprises, Proceedings, 2000, 
Henderson Hall, The University of Newcastle upon Tyne, UK 16-28 April 2000.

[5] Budihardjo, Eko., 1991, Arsitektur dan Kota di Indonesia, Penerbit Alumni 1991, Cetakan ke-3, Bandung,.

[6] Creighton, T.H and Ford, K. M.,Ed., 1961, Contemporary Houses, evaluated by their owners; Reinhold Publishing Corporation, New York.

[7] Habraken, NJ. 1978. The Systematic Design of Support. Massachusset: Laboratory of Arch and Planning MIT, Cambridge.

[8] Haughton, Graham. \& Hunter, Colm., 1994, Sustainable Cities; Regional Policy and Development Series 7; Regional Studies Association, London.

[9] Huque, A. K., 1997, Bunga Rampai Arsitektur ITS ; Usaha Pengentasan Kemiskinan dengan Mencari Pemecahan Masalah Lahan Permukiman Bagi Masyarakat Golongan Ekonomi Lemah di Area Urban, Surabaya.

[10] Hummon, D. M. 1990. Community Attachment: Community Sentiment and Sense of Place.

[11] Juhana, 2001, Arsitektur dalam Kehidupan Masyarakat, Pengaruh Bentukan Arsitektur dan Iklim Terhadap Kenyamanan Thermal Rumah Tinggal Suku Bajoe di Wilayah Pesisir Bajoe Kabupaten Bone Sulawesi Selatan, Penerbit Bendera, Semarang.

[12] Lipton, M., 1980, Familiy, Fungibility, and Formality: Rural Advantages of Informal Non-farm Enterprise versus the Urban-formal state.

[13] Maslow, Abraham. 1954, Hierarchy of Need

[14] Molelong, L., 2000, Metodologi Penelitian Kualitatif; Penerbit PT. Remaja Rosdakarya, Bandung.

[15] Newmark and Thompson. 1977. Self, Space and Shelter: An Introduction to Housing. New York: Harper and Row Publizer Inc.
[16] Rapoport, Amos.,1969, House Form and Culture; Foundation af Cultural Georaphy Series; Prentice-Hall, Inc, USA.

[17] Rapoport, Amos., 1977, Urban Aspect of Urban Form, Pergamon Press, Oxford.

[18] Sarwono, S.W., 1992, Psikologi Lingkungan; PPs Program Studi Psikologi Universitas Indonesia dan PT Gramedia Widiasarana Indonesia, Jakarta.

[19] Silas, Johan., 1993, Housing Beyond Home; Case Study of Surabaya; ITS, Surabaya.

[20] Silas, Johan., 1993, Perumahan: Hunian dan Fungsi lebihnya, Dari Aspek Sumberdaya dan Eksistensi; Pidato Pengukuhan Untuk Jabatan Guru Besar Teknik Arsitektur FTSP ITS Surabaya15 Mei 1993, Surabaya.

[21] Silas, Johan. dkk., 2000, Rumah Produktif, Dalam Dimensi Tradisional dan Pemberdayaan; Laboratorium Perumahan dan Permukiman Jurusan FTSP ITS; UPT Penerbitan ITS, Edisi Pertama, Surabaya.

[22] Steadman, J.P. 1983. Architectural Morphology. : Pion Limeted, London

[23] Subadyo, A. Tutut., 2000, Tata Ruang dan Lingkungan; Perspektif Hubungan Aktivitas Manusia dan Lingkungannya dalam Penataan Ruang, Malang. Pusat Studi Tata Lingkungan \& Bentang Alam Jurusan Arsitektur Universitas Merdeka Malang.

[24] Subadyo, A. Tutut., 2001, Studi Penampilan Bangunan Hunian Ditinjau dari Aspek Kepuasan Penghuni; Bahan mata kuliah seminar arsitektur dan SPA 4 Universitas Merdeka Malang, 2001.

[25] Surakhmad, W., 1980, Pengantar Penelitian Ilmiah, Dasar Metode Teknik; Penerbit Tarsito, Edisi ke-7, Bandung.

[26] Suwardono, S. R., 1996, Monografi Sejarab Kota Malang, CV. Sigma Media, Malang. 
[27] Turner, J. F. C., 1972, Freedom to Build; The Macmillan Company.

[28] Turner, J. F. C., 1976, Housing By People; Towards Autonomy in Buliding Environments; Pantheon Books, New York.

[29] Tutuko, Pindo. \& Faslih, Arman., 2003, Alternatif Pengelolaan Limbah Rumah Produksi Tempe: Usulan Konsep Pengelolaan Limbah Rumah Produktif, Proceeding Seminar Nasional Pascasarjana III2003, Program Pascasarjana Insitut Teknologi Sepuluh Nopember Surabaya.

[30] Tutuko, Pindo., 2003, Alternatif Pengelolaan Limbah Rumah Produktif Kampung Sanan 'Tempe' Malang, Jurnal Ilmu-Ilmu Teknik Diagonal, Volume 4 Nomor 2/Mei 2003, Fakultas Teknik Universitas Merdeka Malang.

[31] Tutuko, Pindo, 2004, Kebijakan Perkembangan Pembangunan Perumahan Terhadap Perubahan Struktur Permukiman, Studi Kasus: Perumaban Pondok Tjandra Indab dan Desa Tambak Sumur Sidoarjo, Jurnal Diagonal, Volume 5, No. 3 / Oktober 2004, Fakultas Teknik Unmer, Malang.

[32] Tutuko, Pindo., 2004, Perkembangan Pola Hunian Rumah Produktif Kampung Sanan "Tempe" Malang, Tesis Program Pasca Sarjana ITS, Surabaya.

[33] Wibisono, Iwan,. 2006, Perubaban Fisik RuangDalam pada Rumah Produktif, Studi Kasus: Usaha Berbasis Rumah tangga (UBR) Sentra Perajin Tempe Sanan< Malang, Tesis Program Pasca Sarjana Universitas Brawijaya, Malang.

[34] Zahnd, M, 1999, Perancangan Kota Secara Terpadu, Teori Perancangan Kota dan Penerapannya, Kanisius, Jakarta.
LAMPIRAN FOTO

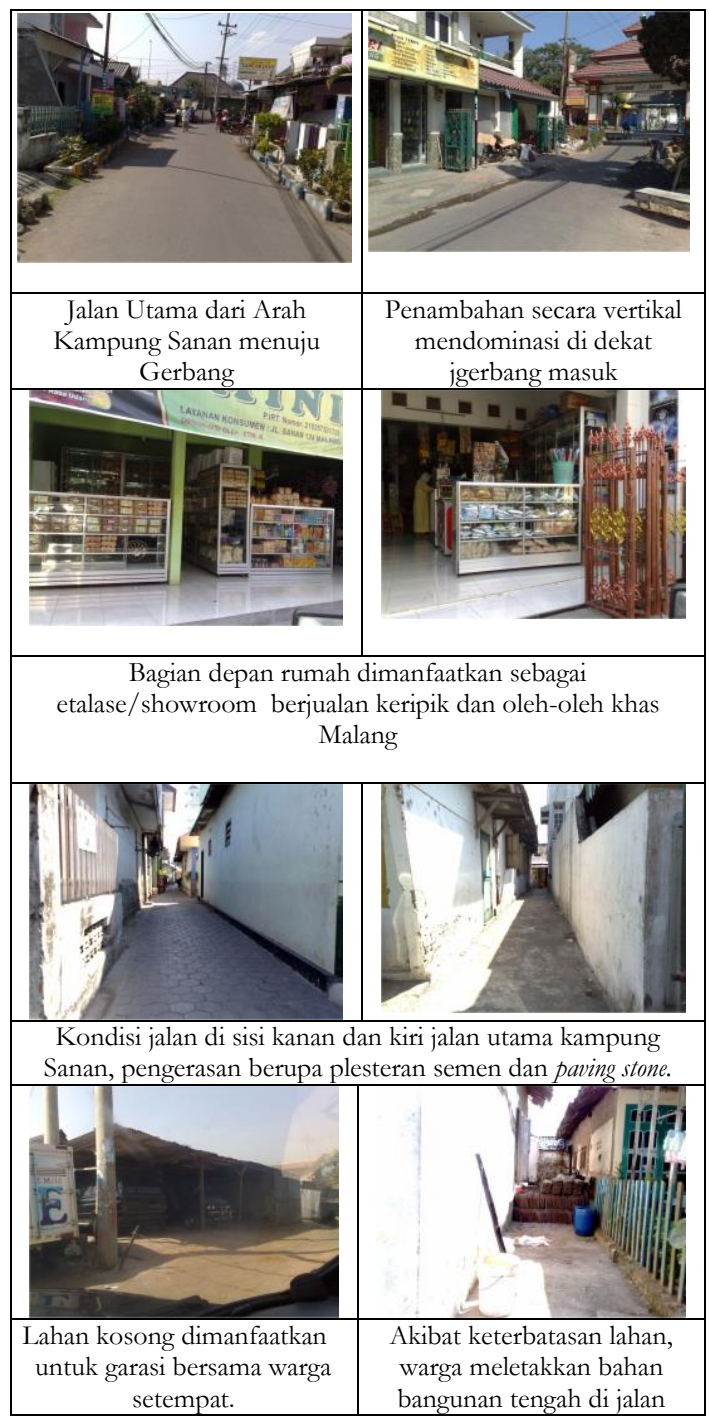




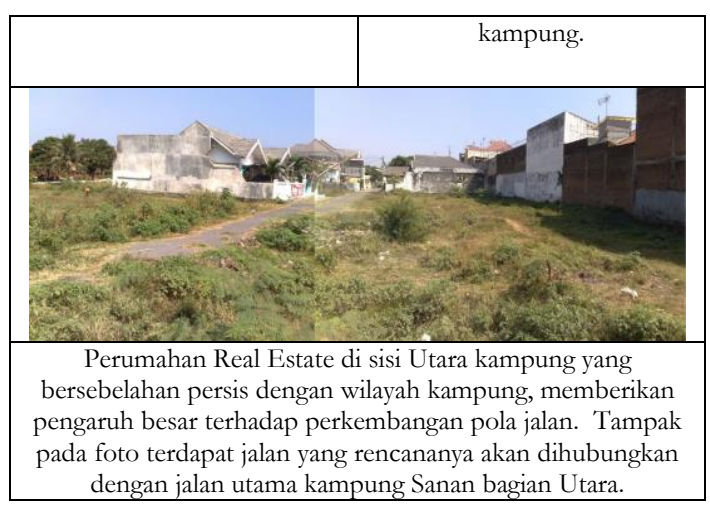

